\title{
The Voice Is the Message: Emotional Practices and Court Rhetoric in Early Twentieth Century Germany
}

SANDRA SCHNÄDELBACH*

Schnädelbach, S., 2019. The Voice is the Message: Emotional Practices and Court Rhetoric in Early Twentieth Century Germany. Received 01 October 2018; Accepted 09 January 2019. Oñati Socio-Legal Series [online], 9(5), 616-635. Available from: https://doi.org/10.35295/osls.iisl/0000-0000-0000-1030

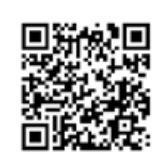

\begin{abstract}
This paper illustrates that emotions were considered a central component of juristic work in German legal thought around 1900, showing how emotional practices of judges were reshaped when they were confronted with new socio-political demands in the early $20^{\text {th }}$ century. It argues that judicial emotions were intensely reflected upon and used by German jurists, especially via court rhetoric and specific politics of voice. It puts forward an understanding of vocal performances as emotional practices that became particularly contested during the first decades of the $20^{\text {th }}$ century. Whereas classical ideals of judicial conduct placed a premium on authority and distance in order to ensure objectivity, a psychologically informed and emotion-based interaction between judges and court attendees came to the fore: the use of rhetoric and the ability of showing, forming, and creating emotions gained relevance. The judge was not only to manage his own emotions, but was conceived of as an active engineer of emotions in court.
\end{abstract}

\section{Key words}

$19^{\text {th }} / 20^{\text {th }}$ century Germany; judicial emotions; politics of voice; rhetoric; history of emotions

\section{Resumen}

El artículo ilustra cómo el pensamiento jurídico alemán de alrededor de 1900 consideraba las emociones un componente central del trabajo judicial, y muestra cómo las prácticas emocionales de los jueces cambiaron a tenor de las nuevas demandas sociopolíticas de principios del siglo XX. Se argumenta que los juristas alemanes usaban intensamente las emociones judiciales. Se definen las actuaciones orales como prácticas emocionales que fueron especialmente contestadas en el siglo XX. Mientras los ideales clásicos sobre la conducta de los jueces ponían el acento en la autoridad y la distancia para garantizar la objetividad, después avanzó un modelo de interacción psicológicamente informada y basada en la emoción: el uso de la retórica y la capacidad de mostrar, formar y crear emociones ganó protagonismo. El juez ya no sólo gestionaba sus propias emociones, sino que se convirtió en un ingeniero activo de emociones en el juzgado.

\footnotetext{
* Postdoctoral Researcher, ERC "BodyCapital", Université de Strasbourg / Center for the History of Emotions, Max Planck Institute for Human Development, Lentzeallee 94, 14195 Berlin, Germany. Email address: schnaedelbach@mpib-berlin.mpg.de
}

\section{(c)) EY-NC-ND}

Oñati International Institute for the Sociology of Law Antigua Universidad s/n - Apdo.28 20560 Oñati - Gipuzkoa - Spain 


\section{Palabras clave}

Alemania en los siglos XIX y XX; emociones judiciales; políticas vocales; retórica; historia de las emociones 


\section{Table of contents / Índice}

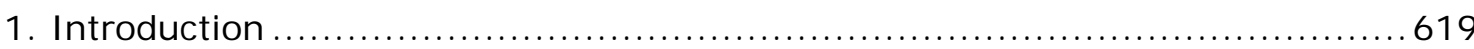

2. The History of Emotions as a History of Legal Feelings........................ 619

3. How Judges Learned to Feel: Emotion Knowledge

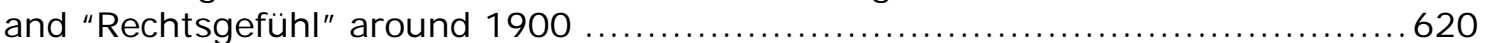

4. Back to the Roots: The Sense of J ustice and the Genesis of Law ................ 621

5. Juristic Work as Emotional Work?

Judges, Judgments and the Search for Scientificity .............................. 622

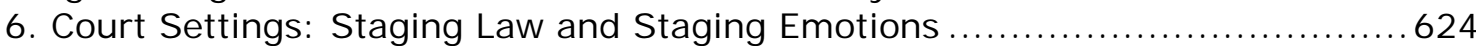

7. The Voice is the Message: Court Rhetoric and Emotions........................626

8. From Emotion Managers to Engineers of Emotions ............................6 629

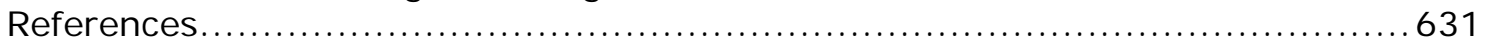




\section{I ntroduction}

The polemical criticism of judges as automatons of decision-making that have lost their souls and mechanically apply the law is - in historical as in contemporary accounts - just as well known as the fear that emotions and subjective evaluations might influence the judge's work for the worse. ${ }^{1}$ At the same time, it is and has always been beyond question that judges, being human beings, do have emotions. In fact, it is exactly the quality of being human that has historically been linked to judicial emotions and that has resulted in a polarization: the sorrow of being too human or not human enough. Analyzing debates in jurisprudence in the Germanspeaking countries around 1900, the actual core problem comes to the fore: The key question was whether jurists and judges should feel differently than the average person. As I argue in this paper, jurists' capacity to navigate their emotions was viewed as a central component of juristic work at the turn of the century. The discussion revolved not around if, but how, when, and what jurists should feel, how they should show their feelings, and, above all, how they should use them. Ideas on a specifically juristic cultivation, display, and usage of emotions, however, underwent a significant change in the early twentieth century.

My paper approaches this shift from the perspective of the history of emotions. After briefly explaining the basic theoretical assumptions of my research, I will trace the ways in which German legal scholars defined and evaluated emotions around 1900. I will then address how these concepts played out in legal practice and emotional practices in court. I argue that emotions were intensely reflected upon and used by German jurists, especially in court rhetoric and a specific politics of voice. Vocal performances, I claim, can be understood as emotional practices, and I will show how judges' use of the voice became particularly contested in the context of fundamental socio-political changes in the early twentieth century.

\section{The History of Emotions as a History of Legal Feelings}

The basic assumption underlying this analysis is that emotions have a history. I claim that emotions are shaped by society and culture, and that depending on the historically specific understanding of what emotions are and how they work, the functions that are attributed to them in a society change. From this perspective, emotions are not understood as fixed "natural" states, but rather as being formed in interaction with culture. I assume that shifts in how emotions are expressed influence how we perceive and interpret them, and vice versa. Emotions are thus part of a social practice that must be learned, trained, and performed (Rosenwein 2010, Plamper 2010, 2015, Scheer 2012). This is not to claim that feelings lack a bodily basis or are independent of physical processes. Rather, this approach seeks to account for the interplay between biological factors and cultural formation. How to measure this relationship exactly, and how to define emotions in general, is the subject of complex scientific debates that go beyond the limits of this essay (for an overview see Plamper 2015 as well as Boddice 2018). What is central for me, however, is the assumption that emotions are more than physical reflexes and cannot be adequately captured in universal categories. My criteria for determining what counts as an emotion is what in a society at a certain time is considered an emotion and perceived as such. In order to make sense of certain states and interpret them as emotions, societies need a concept that makes this interpretation possible in the first place. It is exactly these variable descriptions and conceptions of emotions, I argue, that determine the norms of what, how, where, and when we feel. Emotions are thus part of a constant process of negotiation about their meaning, appropriateness, and articulation.

\footnotetext{
${ }^{1}$ See, for the German context, Ogorek 1986. For recent debates see the discussion on the essays of Fischer 2016.
} 
This also holds true for the role of emotions in law. In fact, this is an especially interesting field as, according to the classical Western narrative, emotions are usually supposed to be entirely bracketed in jurisprudence. The law is, according to the ideal, a sphere of rationality that deals with cognitive, rule-based processes of applying norms. This combination of law or decision-making and rationality can be understood as a "cultural script" that is rooted in the long philosophical tradition of treating cognition and emotion as polar opposites (Maroney 2011). Alternative interpretations, particularly those that interweaved reason and emotion, have often been overlooked in the reception of legal philosophy. In recent years, however, the literature on the history of law and emotion has been growing, particularly with focus on the UK and the USA but also on Europe. ${ }^{2}$ Yet, due to differences in legal traditions - Germany being bound to civil law in contrast to Anglo-American case law to name one - national specificities need to be addressed. This paper contributes to the field in highlighting the German speaking countries that significantly influenced European and even American legal thought in the early twentieth century, showing how debates on juristic emotions are intertwined with broader socio-political questions of the time.

\section{How Judges Learned to Feel: Emotion Knowledge and "Rechtsgefühl" around 1900}

At first it might seem surprising that German jurisprudence dealt intensively with questions of emotions at the turn of the twentieth century. Yet, the relationship between law and emotion, and specifically that between judgment and emotion, was often discussed, igniting a controversy over legal methods that legal scholars of the time perceived as of nothing less than existential significance (Gängel and Mollnau 1992b, Wilhelm 2010, pp. 323-409, 625). From this perspective, it becomes evident that the narrative of juristic rationality was accompanied by an equally widespread narrative of juristic emotionality that gained a new social urgency around 1900. As I argued elsewhere, the period between 1870 and 1933 marked a turning point in which the status of emotions in law was renegotiated. ${ }^{3}$

To map out how jurists defined emotions and how this in turn informed ideas on legal practice, it is worth a close analysis of one emotion in particular: the "Rechtsgefühl", a composite of the German words for law and emotion. Debates on this emotion and especially on the question whether it was to be counted as an emotion at all fueled the juristic controversies around 1900. The concept of Rechtsgefühl gives an excellent example of how knowledge about emotions shifted, both in terms of definitions or "emotional lexicons" (Frevert et al. 2014) as well as in terms of the practices associated with them. In particular, it illustrates just how many-sided and often confusingly variable ideas about emotions could be. Rechtsgefühl had a broad range of meanings: Closely connected to notions of (righteous) anger and sympathy it was often understood as a specific mix or a condensation of these emotions - an emotion based on a specific balance. At the same time it could denote a sense of justice or a juristic intuition. This complexity was due to the fact that the term "Gefühl" originally referred to the tactile sense and was only later used to describe an inner sense, inner movements or emotions. Accordingly, the term "Rechtsgefühl" did not clearly distinguish between sense, feeling or emotion but oscillated between these concepts. It was at the turn to the twentieth century that this openness was conceived as problematic for the first time. The Rechtsgefühl was discussed in contemporaneous legal theory and philosophy, cultural magazines, psychological, and physiological studies, but also in the context of court practice.

The constant recurrence that both scholars of law and their colleagues in other disciplines made to the Rechtsgefühl and concepts of feeling conveys well the fact

\footnotetext{
2 For the eighteenth century, see Seymour 2012, Köhler and Schmidt 2015, Milka and Lemmings 2017. For recent research on the History of Law and Emotions see Kesper-Biermann and Ellerbrock 2015, Rozenblatt 2017, Kounine and Vidor 2017.

${ }^{3}$ For a more thorough analysis see my German monograph (forthcoming in 2019) with Wallstein.
} 
that emotions were regarded as constitutive for the law at the turn of the century. Following philosophical traditions of the nineteenth century, emotions and feelings held functions that were seen as crucial for the development of law and society. As an "inner sense" that expresses itself through emotional reactions, the Rechtsgefühl in particular was considered an important element of legal life. The significance invested in it illustrates how emotions fulfilled a social function, as Rechtsgefühl served to legitimize the law, the legal practice, and jurists themselves. With their capacity to feel the law, jurists and especially judges of the late nineteenth and early twentieth century secured their social and professional status and gave proof of its necessity. An educated Rechtsgefühl was widely understood as the result of the jurist's special ability to "correctly" balance emotion and reason and cultivate certain emotions like love and empathy (Rümelin 1871/1948). In practicing this ability, they marked themselves as possessing a skill that was - at least among most jurists understood as specifically male and bourgeois. While the notion of Rechtsgefühl around 1900 also referred to emotions of non-legal scholars, this paper focuses on the implications it had for judges. The idea of a specifically trained judicial emotionality, it shows, also shaped ideas about certain emotional practices. By discussing different understandings of Rechtsgefühl, jurists equally discussed judicial emotional styles. The controversies reflect how jurists were expected to acquire, apply and display their Rechtsgefühl while at the same time conveying a growing concern with the impact of emotions in court in general.

\section{Back to the Roots: The Sense of J ustice and the Genesis of Law}

Initially, the philosophy of law was the place where the importance of emotions for the law was systematically discussed: How is law to be defined? Where are its origins to be found? These were the basic questions of the field. Beginning in the 1870s, a debate on the role of Rechtsgefühl emerged. It questioned whether there existed anything like an innate sense of justice that informed our emotions and that - if trained and read correctly - might serve as an ethical guideline for the development and application of law. Building on influential German philosophers of the eighteenth century like Johann Gottfried Herder, the widespread claim persisted that the law was not an invention of jurists, but that it arose from a human drive and had its home in man's heart as an innate instinct. ${ }^{4}$ This concept of legal feelings, which found its way into the German language as "Rechtsgefühl" around 1800, was part of an anthropological explanation of law that followed out of the old tradition of natural law (for the tradition of the $18^{\text {th }}$ century see Köhler and Schmidt 2015).

Thus, the notion that people had a sense or a drive for justice was not new at all. What was new, however, was contemporaneous scholars' interest in the function of emotions. Legal feelings were now being interpreted in the context of psychological models, giving them a new scientific force. ${ }^{5}$ This seemed urgently necessary at the time: The flourishing school of legal positivism, which defined law strictly in terms of written statute, had gained dominance in legal discourse and challenged those who believed that the genesis of law was to be found in a sense of justice (Gängel and Mollnau 1992a). Thus, the reevaluations and detailed analyses of the Rechtsgefühl addressed a shift in legal thought, emerging at a time when popular encyclopedias had declared ideas of natural law obsolete. The numerous reflections on the sense of justice around 1900, however, reveal how persistent the idea of a law supposedly anchored in man proved to be.

What made the concept of Rechtsgefühl so attractive was its ability to explain the driving forces behind the genesis of law that had long been vaguely described as "dark functions" of the soul. It allowed jurists to integrate new scientific approaches

\footnotetext{
${ }^{4}$ Most influential for this debate were the writings of Gustav Rümelin (1871/1948) and Rudolf von Jhering (1897).

${ }^{5}$ This was already true of Rümelin's and von J hering's texts and reached a new level of intensity in studies by Sigmund Kornfeld $(1914,1917)$ and Erwin Riezler (1921).
} 
into older concepts of legal feelings. In line with the still young experimental natural sciences that had been established in the second half of the nineteenth century, legal feelings were now defined using the methods of psychology and physiology: Instead of "driving forces", cycles of "energy", strength of "nerves", and "will power" now provided the primary explanations of what emotions were. Rechtsgefühl was measured by muscular activity and blood pressure, with stunning findings and claims about the connection between heart muscle activity and moral sentiments (Knapp 1857, pp. 88-129, 144-246, Stricker 1884, Treiber 1998, pp. 177-186). The conception of emotions as inner senses and rational perceptions of the world gave way to an understanding of emotions as measurable bodily processes. The concept of Rechtsgefühl, however, made it possible to combine these new ideas with older traditions - and therefore remained a central, yet highly debated element of legal thought.

\section{J uristic Work as Emotional Work? Judges, J udgments and the Search for Scientificity}

These concepts of legal feelings also helped shape and legitimize ideas of juristic scientificity - not only relevant to academic scholars, they were also helpful for practitioners and all representatives of the German law, considering that they all underwent the same basic academic training at university.

In line with the narrative about the genesis of law in feelings, German legal theory of the nineteenth century obliged jurists to establish and retain a connection to the collective sense of justice. Following the influential legal theory of Friedrich Carl von Savigny, each instantiation of law and custom was considered to have developed historically in particular linguistic and cultural communities and as "living" in a people's spirit, the "Volksgeist". Legal feelings were accordingly seen as collective feelings that united a legal community. Thus, feeling the law in a professional manner guaranteed that jurists would establish and retain connection to this collective sense of justice. Scholars elucidated the necessity of jurisprudence by claiming that shared legal feelings had to be implemented in systematic law. The Rechtsgefühl was regarded as the irreplaceable instrument of the legal scholar, whose work was based on the perception and translation of an unwritten law into a scientific system (on Savigny see Rückert 1984, pp. 234-241, Lahusen 2013, pp. 57-73).

When emotions at the turn of the twentieth century were less and less defined in an epistemological way as reasonable, world-opening functions and as "inner senses", but as bodily functions and expressions of the will (see Jensen and Morat 2008), feeling the law was increasingly considered problematic, because it was now seen as colliding with standards of scientific objectivity. Jurists demanded a more comprehensive form of emotional control in their day-to-day practice. The harshly led arguments on the question as to whether Rechtsgefühl was a practical sense or intuition based on embodied technical knowledge or whether it referred to emotions and subjective elements of the psyche that required constantly to be kept in check reflect the fact that the particular concept of Rechtsgefühl was key to its varying evaluation in legal practice.

A new and heatedly debated position on this matter was put forth by the German Free Law Movement in the early twentieth century. Its proponents, among them legal scholars like Hermann Kantorowicz and Ernst Fuchs, argued that jurists should more strongly acknowledge legal feelings in the application of law and that scholars should make the Rechtsgefühl itself an object of research. Drawing on the emerging field of sociology, their aim was to undertake an empirical, "sociological" analysis of legal feelings in order to shed new light on processes of legal reasoning and turn emotions into productive forces for judicial decision-making (Gnaeus Flavius [Kantorowicz] 1906, Fuchs 1908/1965). By taking a systematic approach to legal feelings, the Free Law Movement tried to reconnect the ideal of emotion-based legal work with the ideal of scientific objectivity. The vehement critique that the Free Law Movement 
encountered, though, was not only due to the flaws and challenges of its methodology, which, according to critics, did not even deserve to be called one. It also reflects the shift in perspective on legal feelings ushered in by the Free Law Movement: For decades, the debates on Rechtsgefühl had primarily revolved around the genesis of law and its scientific development. Now, the discussion about law and emotions was transferred from legal philosophy into legal methodology and, with that, from the question of the genesis of law to that of the genesis of professional judicial decision-making. Judicial emotions took on a heretofore unheard-of sociopolitical relevance, as they were not only discussed in critical accounts of juries and lay judges, but also in relation to professional judges.

Long-cultivated narratives about legal work that embraced feeling the law or the creative application of law received a new political impetus during the first decades of the twentieth century. With the rise of the social democratic movement and growing political tensions in the German Empire and especially in the politically polarized society of the Weimar Republic after the First World War, jurists showed an increased awareness of the emotional aspects of judicial judgments (Blackbourn 2003, pp. 265-347, further: Grunwald 2012 and Hett 2014). But scholars differed in their definitions of the problem: While many jurists claimed that judicial emotions were given too much room, a growing number of jurists believed that, on the contrary, emotions were paid too little attention, which made them dangerous. Free Law jurists in particular claimed that fair judgments were only possible if judges were aware of the feelings that led them to resolve a case in a particular way and only if they explored the emotional underpinnings of their attitudes in order to then make them productive for legal reasoning. But more moderate colleagues like the president of the Austrian Supreme Court, J oseph Unger, or the German Supreme Court Judge Adelbert Düringer, also acknowledged that their decisions were often if not mainly guided by emotions and intuition - by their Rechtsgefühl (Unger 1906, col. 786, Düringer 1909, p. 7, on the debates of the "Methodenstreit" see Gängel and Mollnau 1992a).

This debate on judicial emotions was part of a major dispute ignited at the turn of the century by massive public criticism of the German judiciary. Judges were accused of executing class justice from the bench and of being detached from real life - claims that came not only from outside, but also from inside the legal sphere itself (Gängel and Mollnau 1992b, Hett 2014, pp. 299-476, 504-510, 577-603). Many jurists lawyers as well as judges - identified as the core of the problem legal practitioners' insufficient emotional education and their suppressed or poorly developed Rechtsgefühl.

Contrary to what one might assume, the key proponents of increasing appreciation for legal feelings were not jurists with conservative or right-wing political persuasions. In the first place, republican lawyers, often drawing on the ideas of the Free Law Movement, insisted on the methodical inclusion of judicial emotions in court practice. The allegations of detachment and class justice, they claimed, could only be confronted if judges changed their emotional attitudes (On polemics about the blindfolded justitia see Rosenblum 2015, with a focus on lawyers see Grunwald 2012). This argument especially gained steam in the years following the establishment of the first German democracy with the foundation of the Weimar Republic. In the 1920s, the explicit goal of the newly established association of republican jurists was to cultivate "republican feelings" (Fuchs 1925/1926, p. 251). Thus, the reforms that jurists demanded at the time often relied on a reformation of judicial emotions. Emotions were not always considered a danger, but rather as a condition of forming a judgment. It is this line of thinking that would become most relevant in the judiciary of the time.

At the turn of the century, jurists demanded in progressively more emphatic terms that their colleagues make productive use of emotions in legal practice. From this perspective, the call for a better educated Rechtsgefühl can be read as a form of 
"emotional labor" (Hochschild 1983), where emotions are adapted to and formed by the requirements of a particular type of work. At the same time, I argue, these demands drew on forms of "emotion work" that the sociologist Arlie Hochschild has defined as forms of managing and modulating one's own emotions in private contexts (for a more detailed argument see Schnädelbach 2015). The concept of Rechtsgefühl was especially influential because it spoke to both levels. It was considered a part of an emotional education that was to first take place in private relations and would then be professionalized in juristic contexts. This entanglement explains why the debates on judicial emotions were so explosive. As jurists around 1900 highlighted the need for their colleagues to cultivate their emotions in a particular fashion, they contested the idea that a good Rechtsgefühl came naturally with a certain social background and a legal degree. Proponents believed that a higher level of emotional self-awareness and scientifically based education was necessary. This idea was fostered by newly emerging scientific fields like experimental psychology that stressed the significance of emotions in social life and also offered new perspectives on their handling.

Spreading in an increasingly politicized society and legal culture, these new takes on judicial Rechtsgefühl marked a starting point for a reevaluation of juristic methods and judicial conduct. As I will show in the following, the ideal judge was defined in a new way during the first decades of the twentieth century. I magined as more than a manager of his own emotions, the ideal judge supposed to fill the role of an emotional engineer who was to shape, make use of, and interact with the emotions of those who came before him in court. Manager and engineer are analytical terms that I use to convey a shift of judicial emotional practices that were systematically conceived as tools for creating certain emotional settings in court.

\section{Court Settings: Staging Law and Staging Emotions}

The idea that court proceedings could or even should have an emotional effect on those involved has been part of legal thought for a long time and is still relevant today (see, for example, Legnaro and Aengenheister 1999 or Jung 2016). The court architecture of the German Empire, however, set new standards. Beginning in the 1870s, so-called "palaces of justice" were erected in numerous cities of the newly united Empire, which far outshined the previous houses of justice both in terms of size and decor. The monumental buildings explicitly appealed to the sacral and imperial architecture of the time, with imposing staircases, halls, and cupolas. The architecture pronounced the power of law and created an emotional space that was already reflected upon by court attendees at the time (Landau 1982, Klemmer et al. 1993, pp. 34-36, 89-111, Hett 2004, p. 16. For work on emotional spaces see Gammerl and Herrn 2015, Großmann and Nielsen 2018).

The "size and force of the law, the victory of right over injustice" was architectonically expressed in these new buildings, contemporaries emphatically stated. "Light and air everywhere", Franz Hoeniger (1906, pp. 15, 16), a German lawyer, praised the Berlin Court of Appeal in 1906. It was the emotional effect that struck him most: "The mighty feeling: 'You are in a place of supreme royal jurisdiction here'".

Evoking this sense of majesty, authority, and sacred awe was exactly what the courts' architects were aiming at. The staging of the law was akin to a staging of power and hierarchy, and the courtroom was part of this. The set up was structured by specific visual axes - the vanishing point was always the judge's bench - and drew on the effect of height differences. The judge's bench was elevated and positioned on a rug at the front of the hall. Huge portraits of German emperors decorated the walls behind the judges. In contrast, the defendant and the lawyer were on the same level with the public. One's own place within the hierarchy of the court became not only visible here, but was also made physically perceptible by the use of several different types of seating, from the most simple wooden chairs to throne-like leather armchairs (Vismann 2011, pp. 32-33, Ortmann 2014, pp. 119-121). 
These forms and rituals were central to court proceedings and constituted their performative dimension: The power of law was not merely staged by legal professionals in front of an audience, but was performed in an interactive play in which all court attendees were involved. Rituals borrowed from religious contexts created a certain emotional setting, even in places where simple buildings had to be used because no palaces of justice were available. Again and again, everyone in the room had to stand up, not only when the judges entered and when the verdict was pronounced, but also every time defendants, witnesses, or jurors were sworn in. The authority and dignity of the court had to be felt at every moment; solemnity and respectfulness were the ideal moods. Particularly important to this end was ensuring silence in the hall and avoiding hustle and bustle. Nothing seemed more detrimental to the court setting than an improper busyness, perhaps caused by a too rapid sequence of oaths, an "up and down, with a lot of noise" that would make a "ridiculous, degrading comedy" out of the court dramaturgy (Kanzleirath Jäger 1855, p. 10, Habermas 2008, pp. 181-183; for recent ethnographic accounts see Wulf 2003).

The presiding judge effectively served as the director of the dramaturgy:

Only very slowly: when [the judge] straightens himself in his chair, whose backrest towers majestically above him, when he senses that the assessors sit just as quietly in their armchairs and have found the most comfortable position for their legs, when he has checked if a window needs to be closed, if the auditorium has filled up and if the messenger is on hand, when he has opened in the file the pinched page on which the decisive opening decision stands, - only then does the presiding judge raise his eyes to the accused, to see a little how he behaves, whether his posture is appropriate, and, in particular, his hand is not found in that trousers' pocket that leads to so many conflicts, most recently to read vice, crime, or innocence out of that face. (Beradt 1909, p. 45)

From the first minute of the trial on, judicial authority was to be established, thereafter determining the rhythm of the proceedings. However, the court proceedings not only served to put hierarchies on display, but also to consolidate them. Following the court rituals, all persons involved confirmed the hierarchy and took on their respective roles. These rules of rank also largely determined what could be emotionally expressed in court and by whom. Articulating emotions often meant risking a transgression. Accordingly, attorney Beradt (1909, p. 45) advised defendants and witnesses that they keep a check on their facial expressions and body language, such as to disdainfully raise one's lips, speaking in a mannered way, or making gestures that showed disagreement or disrespect. How accepted or even expected displays of emotion were to be distinguished from transgressions was the object of a constant process of negotiation fought out between lawyers and judges in particular.

During the proceedings, a key challenge for judges was to keep his own emotions in check and to find the right balance of emotional display in order to be able to claim a good Rechtsgefühl. A judge's ability to create a court dramaturgy with the right emotional set up was often more important for his promotion to higher posts than was his professional knowledge. For example, in 1906 (GStA PK, I. HA, Rep. 84a 1900-1920, p. 186), Judge Bock was recommended for the post of district court director, even though his supervisor's assessment stated that he was "not a particularly ingenious lawyer called to solve difficult legal issues". The decisive factor was rather his "calm, resolute appearance", paired with his "tact", which he would find very useful in "leading hearings". As I will illustrate, old topoi of judicial conduct were increasingly framed as practices of emotional communication and were reflected as part of juristic methodology that set up new standards for emotional self-reflection of judges. 


\section{The Voice is the Message: Court Rhetoric and Emotions}

But how did juristic reflections on emotions translate into practice? How were emotions actually communicated, performed, recognized, and interpreted in court? Following Monique Scheer (2012) I understand emotions as a kind of (social) practice that - as I argue here - was central to juristic practice around 1900. Some elements of emotional articulation have already been mentioned in the quote above: Gestures and facial expressions are often named in the sources, and historically have received much attention as markers of emotion. Less in the focus but equally prominent were specific modes of speaking. I propose to consider vocal articulation in court as an emotional practice through which emotions were performed and (re)produced. The voice, I argue, was the key medium for the articulation and interpretation of judicial emotions. Vocal performance was part of an emotional practice whose function and goals changed from the nineteenth to the early twentieth century - as well as the practices themselves. Whereas the nineteenth century tradition identified the creation of authority, majesty and awe as most relevant, jurists in the first decades of the twentieth century were supposed to establish an atmosphere of openness, sympathy and interaction. In both cases the modes in which judges were supposed to use their voice served to create a certain emotional space. They can be understood as emotional practices not only in their function of producing or fostering emotions in court but also in their relation to specific modes of juristic emotional selfgovernance and emotional display. Politics of voice clearly marked to what extend and to what end emotional articulation was accepted. In accordance with new ideas on the functions and effects of emotions in court proceedings the ways of cultivating, handling, and modeling emotions changed.

On a theoretical level the voice can be described as the "performative phenomenon par excellence", that is characterized by a specific temporality and corporeality (Kolesch and Krämer 2006, p. 11). The meaning(s) the voice generates result out of personal interactions in a shared moment in a shared space, a point that is of considerable relevance for the legal sphere. Judicial performance was (and is) defined by acts of interrogation, listening, and speaking. Indeed, it is only through acts of communication that a "case" itself ever comes into being, a point that still holds true today. To raise his/her voice and to be heard was and is one of the fundamental rights that constitute the legal subject. This drew on the old idea that the voice was closely connected to a person's soul and transported sincere expressions of emotion. As the German writer and jurist Martin Beradt (1909, p. 45) observed in 1909, every defendant impatiently awaited the first word of the judge:

For a face can be disguised, and gestures are not always easy to read. But even in a voice so violent or annoying, there is something that tells us about the human being. Every defendant knows this with the instinct of his nerves tensed from the first moment, and that is why he waits with pain for the first word, a hope from every fuller vowel, a disappointment in every gawked consonant.

This comment illuminates why the voice was understood as a key component of judicial emotional conduct. Law was performed in the medium of voice. The voice of the judge was understood as an active player in court proceedings, a point well conveyed by a scene described by Martin Beradt (1909, pp. 33-34):

But now a voice leaps through the middle of the hall; suddenly, all of a sudden, it seems to have jumped off the Green Table [the judge's bench], flying through the air, and started firing at someone. At whom? At the accused? (At this poor person? What does the raging voice want?) At the audience that is holding its breath (...)? No, this voice has jumped on the witness, on this gentle, even narrative (...). Now more violently (...), recurrently, it sits down on the throat of this man, struggling with every word that he brings out, pushes it back, if it is wrong, pulls it out, if he wants to hold it back.

This judicial voice jumps, chases, fires. It is characterized by aggressiveness and a readiness to fight. The scene is one of a conflict between two voices, two bodies, in 
which the hierarchy is clear from the very first moment. The judicial use of voice is not merely a preparatory element in the discovery of justice. It is a part of the decision-making process itself, as it investigates, evaluates, enforces, judges. The oral nature of the trial makes judging an "event in the language", i.e. something that takes place in shared moments of speech acts (Vismann 2011, p. 113).

These vocal performances posed a challenge to the presiding judge, as they forced him to take on a dual role. On the one hand, he had the power to regulate the speech of all those present, determining the "discourse economy" (Vismann 2011, p. 49). He decided on what was permitted to be voiced on the stage of the court and how. On the other hand, the judge had to represent, stage, and guarantee that the proceedings were open and unbiased, a balance that had to be created through speech acts.

This use of voice in court is closely linked to the use of court rhetoric, which scholars have generally discussed in respect to its long-standing significance for lawyers (an exception is: Vasilyev 2017. For the French tradition of lawyers see Vidor 2017). The central position of the judicial voice in court, though, was met with particular interest in the early twentieth century. Jurists had a pronounced awareness of the dramaturgical challenges in the design of judicial speech acts. Court hearings were based on a politics of voice, which came under increasing critique at the turn of the twentieth century, providing an object of critical reflection for both legal theorists and practitioners.

The debate over the politics of voice in the courtroom was part of a broader reassessment of the hierarchies, both social and professional, that defined the judiciary. Frequently, the conflicts that arose during court proceedings were caused by lapses in speech that were perceived as defamatory insults. Time and again, disciplinary measures taken against lawyers or judges in the early twentieth century revolved around an interpretation of the tone that had been used. Not only what, but above all how something was said, was decisive. A complaint against district court judge van Dühren in 1930 (Geheimes Staatsarchiv Preußischer Kulturbesitz hereinafter GStA - PK, I. HA Rep. 84a 1928-1931) remained without consequences on the grounds that all those involved in the proceedings confirmed that the judge's statement about the applicant being "rather stubborn" had been expressed in a friendly tone. The crucial point was not whether he had really spoken in a friendly tone or not, but rather the conviction that underlies it: It was universally agreed upon that the judge's style of speaking revealed his emotional attitude and that a correct use of voice was decisive for the evaluation of judicial conduct.

In another case (GStA PK, I. HA Rep. 84a 1900-1924, pp. 11, 25), a lawyer named Halpert complained before the Major Disciplinary Senate in 1900 about a municipal court judge. Although the conflict was based upon a formal mistake of the judge, the lawyer was found responsible for escalating the situation. As the Disciplinary Senate's decision stated:

Dr. Halpert was incensed and engaged in non-apologetic disorderly behavior, blaming the judge in a screaming tone, and even preparing to label his behavior impertinent. An attorney who forgets himself to this extent robs himself of his (...) right to treatment commensurate with the dignity of his profession and must accept that he (...) is asked to leave the room and in case of refusal is removed.

At issue was thus not the judge's formal mistake. What counted instead were questions of honor and dignity and the question of how their violation was to be expressed. While a formal written complaint about the judicial conduct would have been accepted, its emotional articulation in "a screamed tone" was not permitted, as it was considered an attack on judicial authority. For lawyers, successfully controlling their emotions was a prerequisite for being treated by the judge in a dignified manner. 
How did jurists learn about the limits of emotional expression? From the nineteenth century on, the publication of manuals on juristic rhetoric, which also established norms of conduct, became a sort of cottage industry. The rules on how emotions were to be displayed were based on cultural conventions, which were already understood as such. These conventions were consciously wielded to distinguish German courts from their French neighbors, for example, who were considered too sensitive. Lawyers crying was seen as a typically French form of emotional excess. Those who could "only stammer with tears" would no longer be useful as defenders, a book on court rhetoric from the mid-nineteenth century noted. Even in restrained crying, however, the authors (Schall and Boger 1855, pp. 121, 122) recognized a danger:

For us a weeping defender would be a most conspicuous apparition, which would under no circumstances bring happiness. A subdued voice, a moving tone, and some broken words are the expressions of inner movement which the court speaker is not allowed to exceed in our country, without hurting our sense of propriety.

Inherited from the nineteenth century, the strictures placed on judges' expressions of emotion were even tighter. Judges had to engage in a sensitive rhetorical balancing act, a venture fraught with pitfalls. "If only a single jocular expression, a single ridiculous phrase, a single ignoble word escapes his mouth", Heinrich Brinkmann (1826, pp. 125-128) warned, "the judge falls out of his serious and dignified attitude". In the choice of tone, therefore, the judge possessed "no freedom at all": calmness and sincerity were to shape his speech in order to avoid "falling out of the right tone under any circumstances, however tempting they may be". Following the ancient tradition of rhetoric, choice of vocabulary and conduct of voice went hand in hand in legal rhetoric as well. Speaking "passionately", "exuberantly", or even "vividly" was highly disapproved of, just as humor and laughter were considered unworthy of the dignity of the judge. Mastering the voice in order to prevent an unwitting exposure of one's feelings was the central task and challenge. Court rhetoric was part of an emotional practice that aimed not only at certain displays of emotion (or at avoiding them) but was also based upon and actively shaped certain forms of judicial identity and self-relation.

In the first decades of the twentieth century, however, the criteria for what counted as successful judicial rhetoric changed. Even though guide books still referred to ideals such as objectivity and sobriety in order to support their broader arguments on how judges should manage their emotions, they now meant something different. Well-measured formality was out, while freshness and liveliness of speech were now counted among the most important values. These new norms were connected to broader developments in the legal sphere. The judicial politics of voice had become a choice object of contemporary criticism of the judiciary: Using the topos of an allegedly excessive legal formalism, the authors of manuals on court language and rhetoric joined the great chorus of those who complained about the judiciary's lack of flexibility and emotional competence. ${ }^{6}$

The Thuringian judge Richard Deinhardt (1910, pp. 68, 67, 73, similar Daubenspeck 1893) identified judicial language as a central element of what he thought were urgently needed reforms of court practice. Judicial speech, he argued, should not be characterized by "comfortable tranquility"; rather, he believed that language should be "lively" and "educated by ear". "The inner essence of justice", so he claimed in 1910, "must also appear in the outer form, in expression and language". "What moves us in the innermost", he wrote, should be made explicit. He thus advised that judges seek the "truest, most direct expression" instead of letting "the seriousness of the profession" freeze him.

While lawyers were generally criticized for their excessively exaggerating their feelings, judges were usually criticized for their exaggerated matter-of-factness, even

\footnotetext{
${ }^{6}$ On the critique against the judiciary, see Wilhelm 2010.
} 
stiffness, which critics saw as determining their style of conducting court proceedings. This style, in turn, was considered an important factor in crisis of justice that was widely perceived in society. Beginning in the 1890s, the German judiciary had been confronted with harsh criticism about inappropriate verdicts, politically biased decisions, and an overall lack of sensitivity (Siemens 2005, Wilhelm 2010, p. 323, Rosenblum 2015). In the aftermath of the First World War and with intensifying economic and sociopolitical conflicts, the general dissatisfaction with the justice system even increased (Hett 2014). In this context, the use of the judicial voice came to be seen as a highly influential means of optimizing court practice. The judicial politics of voice now came under scrutiny with regard to the emotional messages they communicated. A new, critical reevaluation of hierarchy came to the fore and paved the way for a change of emotional practices in court. These practices concerned judicial self-perception as well as displays of emotion. They actually merged the personal and the professional or, rather, were built on the belief that emotional practices needed to be rooted in the private sphere to succeed in the professional one.

\section{From Emotion Managers to Engineers of Emotions}

The ideal of "spiritedness" that judges were often committed to was now increasingly rejected. Originating in the military sphere, this term referred to ideals of courage, determination, and "the habit of expressing oneself brightly and sharply" (Zacharias 1911 , p. 8). In the eyes of critical jurists, though, this ran counter to the actual demands of judicial work. According to Hamburg judge Adolf Nikolas Zacharias (1911, pp. 8-15), the incisiveness of the officer type might be fitting for the parade ground, but in the courtroom, it is "inhibiting, damaging and even destructive". For Zacharias, the judge should be able to recognize the different "states of mind" of the people coming in front of court. His usage of tone and voice should take into account the exceptional situation in which they found themselves. The judge was supposed to assess the emotional state of the defendants, witnesses, and plaintiffs and tailor his choice of expression to them. The judge's tone, Zacharias wrote, could exert a decisive influence on the course of the hearing. A certain tone of voice was demanded not just during the interrogation of "particularly sensitive personalities"; in court, he recognized, all people are seized by nervousness and concerns about making mistakes, which often led to "paralysis".

Highlighting these new politics of voice, jurists aimed at creating an atmosphere that might cushion the psychological pressure in court and allow the attendees to open up to the judge. "To break down barriers" was the goal that was to be guaranteed by the right judicial attitude. The task consisted judges letting the "inner person shine through" in their "outer nature and behavior". The judge's appearance, facial expressions, and speech were understood as key factors in improving their interactions with the respondents. Referring to contemporaneous psychological studies, Zacharias claimed that the person who "feels" the goodwill of the judge would have an easier time "thinking, remembering, and speaking", thus facilitating the court's aim of discovering the truth (Zacharias 1911, pp. 8-15). Thus, he advised judges to counteract the negative emotional effects of the court situation through the use of their own positive feelings. They were supposed to adopt an attitude of "emotional permeability" in order to develop a sensibility for the emotions of others, with the ultimate aim of influencing these emotions.

In the early twentieth century, legal scholars and practitioners increasingly emphasized how important the correct judicial handling of emotions was for finding the truth. This was connected to the fact that traditional understandings of judicial authority were becoming discredited. Jurists saw the causes for the crisis of justice in structural and methodological shortcomings of the legal system, but pointed to a core problem as well: The inadequate emotional training of the judiciary. In this regard, jurists went along with the press, which had found a favorite topic in lambasting the emotional shortcomings within legal practice; indeed, its open 
criticisms encountered serious resistance from judges (Hett 2014). Reform-oriented, left-liberal jurists, however, strove to make a new emotional attitude the standard in the judiciary: They wanted to replace mechanisms of social distinction from lower classes that were common in bourgeois circles (to which judges belonged) with emotional openness. To reestablish trust in the judiciary, reformers claimed, an emotional bond was necessary that could only be established through a mutual knowledge of life circumstances, ways of speaking, and values (On the reform discourse see Siemens 2005, Wilhelm 2010).

These accounts of opening-up were supported by the findings of contemporary criminal psychology (Gross 1905, pp. 16-49), which reaffirmed the need for judges to engage in more reflection on how they managed their emotions: Only if the judge succeeded in creating a benevolent atmosphere by cultivating positive emotions through voice and gestures could similar emotions be evoked in defendants and witnesses. Producing fear, nervousness, and pressure in court would only serve to negatively affect the memory and speech of defendants and others and thus have a negative impact on the court's ability to find the truth. Emotional practices in court were now reflected as such and methodologically reevaluated.

In the early twentieth century, the discipline of criminal psychology was on its rise. A key figure in the field in Germany was criminal law professor, former prosecutor, and investigating judge Hans Gross. In his influential manual for judges from 1905 (Gross 1905, pp. 55, 56), he identified a connection between the "timbres" of the voice and emotional states. Drawing on Charles Darwin, he wrote: "A person who quietly complains of bad treatment, or suffers insignificantly, almost always speaks in a high tone. Deep groaning, or high piercing screaming shows extreme pain". Concerning court practice, Gross attempted to decipher the meanings of the "halfhigh tone" of voice ("questioning, uncertain"), the "mysterious tone" ("querulous person"), and "hoarse and halting" speech ("the really deeply hurt").

This criminalistic knowledge was framed as something that could help judges interpret statements. But beyond that, it was also supposed to serve as a practical guide that might teach them to train their own style of speaking. According to Gross (1905, pp. 16-19, 198), an open, attentive, vivacious judicial attitude would ensure that the parties involved in the trial were "infected" with it. These claims transferred themes of classical rhetoric into a psychological frame of interpretation and placed a new emphasis on the judge. Liveliness and interest of the judge were to ensure the "right (...) psychological treatment" of those involved. A judge should, Gross stated, act as "psychologist". He pitched the emotional conduct of the judge as a methodological element of criminal psychology. According to him, the judge had the task of "educating" the interviewees on how to be "good witnesses", which he thought could be achieved by transferring one's own emotional openness to the other person.

In contemporary terms (Zacharias 1911, p. 61), the judge was a psychologist, educator, and even a "therapist". His job was not only to mold his own emotions, but also to have a productive influence on those of others. He appeared not only as a manager, but also as an engineer of emotions. Whereas classical ideals of judicial conduct placed a premium on keeping distance in order to ensure objectivity, the psychologically informed, emotion-based interaction between judges and court attendees that came to the fore during the first decades of the twentieth century held that showing, forming, and creating emotions were crucial acts in the courtroom setting. Classically attributed to lawyers, they now took on increasing relevance for the men in black robes.

In the last decades of the German Empire and even more strongly in the politically divided society of the Weimar Republic, liberal jurists and the public came, for the first time, to grasp the social functions of law. The polemic against the symbol of the blindfold of Justitia that arose during the Weimar Republic is telling here: the blindness of Justitia no longer stood for securing objectivity and a judiciary uninfluenced by social and political concerns, but was increasingly associated with 
ignorance and cold-heartedness. The concern that Justitia's blindness could be read as a lack of empathy was so great that the Ministry of J ustice eventually decided not to use blindfolds in future depictions of her (Rosenblum 2015).

This reaction was closely linked to the widespread accusations that German judges "hid" from their feelings or "cut them off": "The suffering he inflicts leaves him no sting, he feels no pain", Martin Beradt (1930, p. 12) wrote in a critique of the judiciary. Court reporters like the well-known journalist Paul Schlesinger (Sling 1929, 2013a, pp. 363, 361) emphasized the internal psychological turmoil involved in developing a judgment as an important aspect of judging as well and, following an old topos, placed it in opposition to the emotionless administration of law. A judge who only administers the law "will often silence his heart", Schlesinger noted in the 1920s, identifying this approach as a cause of the ongoing crisis of justice. In contrast, Schlesinger held that judges had to expose themselves to the suffering brought into the courtroom. But the "official" type of judge, Schlesinger continued, sits "rosy, correct, and decorative" at his table. "His cool, straight attitude makes it impossible for any excesses to occur before his chair", and "when judging, he calmly looks for a middle course, and he finds it without an inner struggle becoming visible (...). The verdict flows coolly from his lips".

Schlesinger understood the capacity to feel and show compassion as a necessary part of the judge's toolbox. On the one hand, this would help the judge better understand the complexities of the individuals before him. On the other hand, and this was the novelty of his thought, he also believed that this capacity should allow the judge to compensate for the limits of the judiciary and the imperfections of the law itself. By dismissing the "pinch of correctness", Schlesinger (Sling 2013b, p. 21) hoped, the judge would be able to compensate for the fallibility of judicial practice. "There is no objectivity. Neither in science nor at the judge's bench. Even the photographic lens is not objective. Helmholtz said he would send the human eye back to the optician if he had ordered it from him - so flawed was its construction. We all live from conventions: visual, acoustic, emotional."

With these words, Schlesinger not only called into question the norms of legal objectivity. He also stated clearly what he thought constituted the crucial factor of legal judgment: namely, conventions of feeling. Emotions, contemporaries believed, were constitutive of the law at the turn of the twentieth century. Although the Weimar Republic is often seen through the lens of what followed it, the examples here demonstrate well that, the attempt to forge a strong relation between law and emotions cannot be attributed to one specific political or ideological conviction, but was propagated by diverse camps from the right as well as the left. In the end, the vision of an emotionally informed justice as conceived of by Schlesinger was not able to escape the perversion of justice that followed.

\section{References}

Beradt, M., 1909. Der Richter. Frankfurt am Main: Rütten \& Loening.

Beradt, M., 1930. Der deutsche Richter. Frankfurt am Main: Rütten \& Loening.

Blackbourn, D., 2003. History of Germany 1780-1918: The Long Nineteenth Century. $2^{\text {nd }}$ ed. London: Blackwell.

Boddice, R., 2018. The History of Emotions. Manchester University Press.

Brinkmann, H.R., 1826. Über die richterlichen Urtheilsgründe, nach ihrer Nützlichkeit und Nothwendigkeit, so wie über ihre Auffindung, Entwickelung und Anordnung: nebst Bemerkungen über den richterlichen Stil und Ton. Kiel: Maak.

Daubenspeck, H., 1893. Die Sprache in gerichtlichen Entscheidungen. Berlin: F. Vahlen. 
Deinhardt, R., 1910. Praktische Justiz! Einfaches Schreibwerk: zweiter Teil zu Erfahrungen und Anregungen zur Kunst der Rechtspflege. Jena: H. Pohle.

Düringer, A., 1909. Richter und Rechtsprechung. Leipzig: Veit.

Fischer, T., 2016. Im Recht: Einlassungen von Deutschlands bekanntestem Strafrichter. Munich: Droemer.

Frevert, U., et al., 2014. Emotional Lexicons: Continuity and Change in the Vocabulary of Feeling 1700-2000. Oxford University Press.

Fuchs, E., 1925/1926. Die Deutsche Richterzeitung und die "Justiz“. Die Justiz, 1, 248-252.

Fuchs, E., 1965. Recht und Wahrheit in unserer heutigen Justiz. In: A.S. Foulkes and A. Kaufmann, eds., Gerechtigkeitswissenschaft: Ausgewählte Schriften zur Freirechtslehre. Karlsruhe: Müller, 65-165. (Originally published in 1908).

Gammerl, B., and Herrn, R., 2015. Gefühlsräume - Raumgefühle: Perspektiven auf die Verschränkung von emotionalen Praktiken und Topographien der Moderne. sublurban. Zeitschrift für kritische Stadtforschung [online], 3(2), 7-21.

Available from: http://www.zeitschriftsuburban.de/sys/index.php/suburban/article/view/190 [Accessed 9 J anuary 2019].

Gängel, A., and Mollnau, K.A., eds., 1992a. Gesetzesbindung und Richterfreiheit: Texte zur Methodendebatte 1900-1914. Freiburg: Haufe.

Gängel, A., and Mollnau, K.A., 1992b. Stationen der Methodenreformbewegung in Deutschland oder Richterabsolutismus contra Gesetzesabsolutismus? In: A. Gängel and K.A. Mollnau, eds., Gesetzesbindung und Richterfreiheit: Texte zur Methodendebatte 1900-1914. Freiburg: Haufe, 295-340.

Gnaeus Flavius (H. Kantorowicz), 1906. Der Kampf um die Rechtswissenschaft. Heidelberg: C. Winter.

Gross, H., 1905. Kriminal-Psychologie. Leipzig: Vogel.

Großmann, T., and Nielsen, P., eds., 2018. Introduction: architectural history of emotions - emotional history of democracy. In: T. Großmann and P. Nielsen, eds., Architecture, Democracy, and Emotions. New York: Routledge, 1-17.

Grunwald, H., 2012. Courtroom to Revolutionary Stage: Performance and I deology in Weimar Political Trials. Oxford University Press.

GStA PK, I. HA Rep. 84a, 1928-1931. Kammergerichtsbezirk Berlin. Personalangelegenheiten, Allgemein. Beleidigung von Beamten und Strafanzeigen gegen sie, 1 (30171).

GStA PK, I. HA, Rep. 84, 1900-1920. Zur Beförderung in höhere Stellen geeignete richterliche Beamte und Staatsanwälte, 2 (20201).

GStA PK, I. HA, Rep. 84a, 1900-1924. Die Dienstvergehen der richterlichen Beamten, 5 (3061).

Habermas, R., 2008. Diebe vor Gericht: die Entstehung der modernen Rechtsordnung im 19. J ahrhundert. Frankfurt am Main: Campus, 181-183.

Hett, B.C., 2004. Death in the Tiergarten: Murder and Criminal J ustice in the Kaiser's Berlin. Cambridge, MA: Harvard University Press.

Hett, B.C., 2014. Justice is blind: crowds, irrationality, and criminal law in the late Kaiserreich. In: R.F. Wetzell, ed., Crime and Criminal J ustice in Modern Germany. New York: Berghahn Books, 31-55.

Hochschild, A.R., 1983. The Managed Heart: Commercialization of Human Feeling. Berkeley: University of California Press. 
Hoeniger, F., 1906. Berliner Gerichte. Berlin: Seemann.

J ensen, U., and Morat, D., eds., 2008. Rationalisierungen des Gefühls: zum Verhältnis von Wissenschaft und Emotionen 1880-1930. Munich: Fink.

J hering, R.v., 1897. Der Kampf um's Recht. Vienna: Manz.

Jung, H., 2016. Rituals and Procedure. In: B. Ackerman, K. Ambos and H. Sikirić, eds., Visions of J ustice. Berlin: Duncker \& Humblot, 259-271.

Kanzleirath Jäger, 1855. Bemerkungen für Gesetzgebung und Praxis des Strafverfahrens. Hitzig's Annalen der deutschen und ausländischen CriminalRechtspflege N.F., 40, 1-13 and 101-116.

Kesper-Biermann, S., and Ellerbrock, D., eds., 2015. Between passion and senses? Perspectives on emotions and law. InterDisciplines, 6(2).

Klemmer, K., Wassermann, R., and Wessel, T.M., eds., 1993. Deutsche Gerichtsgebäude: von der Dorflinde über den Justizpalast zum Haus des Rechts. Munich: C.H. Beck.

Knapp, L., 1857. System der Rechtsphilosophie. Erlangen: Enke.

Köhler, S.G., and Schmidt, F., 2015. Enigmatic grounds: on the genesis of law out of emotion in the writings of Savigny and Uhland. InterDisciplines, 6(2), 1746.

Kolesch, D., and Krämer, S., 2006. Stimmen im Konzert der Disziplinen: zur Einführung in diesen Band. In: D. Kolesch and S. Krämer, eds., Stimme: Annäherung an ein Phänomen. Frankfurt am Main: Suhrkamp, 7-15.

Kornfeld, S., 1914. Das Rechtsgefühl. Zeitschrift für Rechtsphilosophie in Lehre und Praxis, 1, 135-187.

Kornfeld, S., 1917. Das Rechtsgefühl. Zeitschrift für Rechtsphilosophie in Lehre und Praxis, 2, 28-100.

Kounine, L., and Vidor, G.M., eds., 2017. Law and emotions. Journal of Social History [online], 51(2). Available from: https://doi.org/10.1093/jsh/shx005 [Accessed 9 January 2019].

Lahusen, B., 2013. Alles Recht geht vom Volksgeist aus: Friedrich Carl von Savigny und die moderne Rechtswissenschaft. Berlin: Nicolai.

Landau, P., 1982. Reichsjustizgesetze und Justizpaläste. In: E. Mai, H. Pohl and S. Waetzoldt, eds., Kunstpolitik und Kunstförderung im Kaiserreich. Berlin: Mann.

Legnaro, A., and Aengenheister, A., 1999. Die Aufführung von Strafrecht: Kleine Ethnographie gerichtlichen Verhandelns. Baden-Baden: Nomos.

Maroney, T.A., 2011. The persistent cultural script of judicial dispassion. California Law Review [online], 99(2), 629-681. Available from: https://doi.org/10.15779/Z38K98M [Accessed 9 J anuary 2019].

Milka, A., and Lemmings, D., 2017. Narratives of Feeling and Majesty: Mediated Emotions in the Eighteenth-Century Criminal Courtroom. The J ournal of Legal History [online], 38(2), 155-178. Available from: https://doi.org/10.1080/01440365.2017.1336891 [Accessed 9 January 2019].

Ogorek, R., 1986. Richterkönig oder Subsumtionsautomat? Zur J ustiztheorie im 19. Jahrhundert. Frankfurt am Main: Klostermann.

Ortmann, A., 2014. Machtvolle Verhandlungen: zur Kulturgeschichte der deutschen Strafjustiz 1879-1924. Göttingen: Vandenhoeck \& Ruprecht.

Plamper, J., 2010. The History of Emotions: an Interview with William Reddy, Barbara Rosenwein, and Peter Sterns. History and Theory [online], 49(2), 
237-265. Available from: https://doi.org/10.1111/j.1468-2303.2010.00541.x [Accessed 9 January 2019].

Plamper, J., 2015. The History of Emotions: An Introduction. Oxford University Press.

Riezler, E., 1921. Das Rechtsgefühl: rechtspsychologische Betrachtungen. Munich: Schweitzer.

Rosenblum, W., 2015. Serene Justitia and the passions of the public sphere. InterDisciplines [online], 6(2), 101-130. Available from: https://doi.org/10.4119/UNIBI/indi-v6-i2-141 [Accessed 9 J anuary 2019].

Rosenwein, B.H., 2010. Problems and methods in the history of emotions. Passions in Context. Journal of the History and Theory of Emotions [online], 1(1), 1-33. Available from: https://www.passionsincontext.de/uploads/media/01_Rosenwein.pdf [Accessed 9 January 2019].

Rozenblatt, D., ed., 2017. Criminal law and emotions in modern Europe: historical perspectives. Rechtsgeschichte [online], 25. Available from: https://doi.org/10.12946/rg25/242-250 [Accessed 9 J anuary 2019].

Rückert, J., 1984. Idealismus, J urisprudenz und Politik bei Friedrich Carl von Savigny. Ebelsbach: Gremer.

Rümelin, G., 1948. Über das Rechtsgefühl. In: G. Rümelin, Rechtsgefühl und Gerechtigkeit. Frankfurt am Main: Klostermann, 3-22. (Originally published in 1871).

Schall, W., and Boger, E., 1855. Vorschule der gerichtlichen Beredsamkeit für Rechts-Anwälte. Schwäbisch Hall: W. Nitzschke.

Scheer, M., 2012. Are emotions a kind of practice (and is that what makes them have a history)? A Bourdieuian approach to understanding emotion. History and Theory [online], 51(2), 193-220. Available from:

https://doi.org/10.1111/j.1468-2303.2012.00621.x [Accessed 9 January 2019].

Schnädelbach, S., 2015. The jurist as manager of emotions: German debates on "Rechtsgefühl" in the late 19th and early 20th century as sites of negotiating the juristic treatment of emotions. InterDisciplines [online], 6(2), 47-73. Available from: https://doi.org/10.4119/UNIBI/indi-v6-i2-143 [Accessed 9 January 2019].

Seymour, M., 2012. Emotional arenas: from provincial circus to national courtroom in late nineteenth-century Italy. Rethinking History [online], 16(2), 177-197. Available from: https://doi.org/10.1080/13642529.2012.681190 [Accessed 9 January 2019].

Siemens, D., 2005. Die „Vertrauenskrise“ der Justiz. In: M. Föllmer and R. Graf, eds., Die „Krise“ der Weimarer Republik: zur Kritik eines Deutungsmusters. Frankfurt am Main: Campus, 139-163.

Sling (Paul Schlesinger), 1929. Richterporträts aus Moabit. In: Sling, Richter und Gerichtete. Berlin: Ullstein, 355-364.

Sling (Paul Schlesinger), 2013a. Richterporträts aus Moabit. In: Sling, Der Mensch, der schießt: Berichte aus dem Gerichtssaal. Düsseldorf: Lilienfeld, 359-367.

Sling (Paul Schlesinger), 2013b. Wie ich Gerichts-Berichterstatter wurde. In: Sling, Der Mensch, der schießt: Berichte aus dem Gerichtssaal. Düsseldorf: Lilienfeld, 20-22.

Stricker, S., 1884. Physiologie des Rechts. Vienna: Toeplitz \& Deuticke. 
Treiber, H., 1998. Zur Physiologie des Rechts oder Der Muskel als Scharnierbegriff. In: P. Sarasin and J. Tanner, eds., Physiologie und industrielle Gesellschaft: Studien zur Verwissenschaftlichung des Körpers im 19. und 20. Jahrhundert. Frankfurt am Main: Suhrkamp, 170-203.

Unger, J., 1906. Der Kampf um die Rechtswissenschaft. Deutsche Juristen-Zeitung, 14, col. 781-786.

Vasilyev, P., 2017. Beyond dispassion: emotions and judicial decision-making in modern Europe. Rechtsgeschichte [online], 25, 277-285. Available from: http://dx. doi.org/10.12946/rg25/277-285 [Accessed 9 J anuary 2019].

Vidor, G.M., 2017. Rhetorical engineering of emotions in the courtroom: the case of lawyers in modern France. Rechtsgeschichte [online], 25, 286-295. Available from: http://dx.doi.org/10.12946/rg25/286-295 [Accessed 9 J anuary 2019].

Vismann, C., 2011. Medien der Rechtsprechung. Frankfurt am Main: S. Fischer.

Wilhelm, U., 2010. Das deutsche Kaiserreich und seine Justiz: Justizkritik politische Strafrechtsprechung - Justizpolitik. Berlin: Duncker \& Humblot.

Wulf, C., 2003. Ritual und Recht: performatives Handeln und mimetisches Wissen. In: L. Schwarte and C. Wulf, eds., Körper und Recht: anthropologische Dimensionen der Rechtsphilosophie. Munich: Fink, 27-45.

Zacharias, A.N., 1911. Ueber Persönlichkeit, Aufgaben und Ausbildung des Richters. Berlin: Guttentag. 